\title{
Wariacje Na Temat STarości W OpoWiadaniach Brunona SCHUlza
}

W centrum zainteresowań Brunona Schulza często znajdowały się osoby egzystujące na marginesach głównego nurtu życia: ludzie starzy (Jakub, bohaterowie opowiadań Emeryt i Samotność), dotknięci kalectwem (Edzio) oraz upośledzeni umysłowo (Dodo, wuj Hieronim, żebraczka Tłuja) ${ }^{1}$.

Wykorzystanie przez artystę tego rodzaju postaci pełni dwojaką funkcję: stały się one inspiracją do powstania interesujących opisów ${ }^{2}$, a ponadto ich obecność na kartach opowiadań dała okazję, by zespolić tworzywo prozy poetyckiej z szeroko pojmowaną problematyką społeczną. Uwaga ta jest bardzo istotna, ponieważ utwory Wielkiego Drohobyczanina na ogół odczytuje się w kategoriach czysto estetycznych, podczas gdy wpisane są w nie również doniosłe zagadnienia współczesnego świata. Pod tym względem autor Wiosny zadziwiająco trafnie przepowiedział, jakie zadania będą wyzwaniem ludzi w XX i XXI wieku. Jednym z nich jest wciąż otwarty problem starzejącego się społeczeństwa, implikujący pytanie, jak godnie doświadczać jesieni życiả. Według Georgesa Minoisa, autora interdyscyplinarnej pracy Historia starości. Od antyku do renesansu, współcześnie stary człowiek, niegdyś reprezentujący mniejszość, zasila szereg coraz liczniejszej grupy obywateli, a późny wiek, do niedawna prywatna sprawa każdej rodziny, staje się zjawiskiem społecznym na ogromną skalę

\footnotetext{
*Aleksandra Smusz — doktorantka literaturoznawstwa na Wydziale Filologicznym Uniwersytetu Rzeszowskiego. Finalistka XIII edycji ogólnopolskiego konkursu na najlepszą polonistyczną pracę magisterską imienia Czesława Zgorzelskiego. Publikowała na łamach „Czasu Kultury”. Jej zainteresowania naukowe to proza awangardowa dwudziestolecia międzywojennego, antropologia literatury. Przygotowuje rozprawę doktorską na temat Nieoswojone strategie interpretacyjne twórczości Brunona Schulza.

${ }^{1}$ Zob. A. Smusz, Schulz i kalecy. Figury ułomności w opowiadaniach Brunona Schulza, „Czas Kultury”, R. 30: 2014, nr 1, s. 38-45. Do grupy „istnień marginesowych” należy także zaliczyć wuja Edwarda, który wskutek pasji eksperymentatorskiej ojca Józefa zmienił się w dzwonek elektryczny, stając się cyborgiem ograniczonym do wykonywania tylko jednej, ściśle określonej czynności.

${ }^{2}$ J. Speina, Bankructwo realności. Proza Brunona Schulza, Warszawa-Poznań 1974, s. 31.

${ }^{3}$ Jean-Pierre Bois wyjaśnił, że współcześnie ludzie wcale nie żyją dłużej niż kiedyś - maksymalna granica wieku, jaki może osiągnąć człowiek, utrzymuje się na podobnym poziomie od tysięcy lat. W porównaniu z przeszłością zmieniło się natomiast to, że znacznie większa liczba osób dożywa starości i wzrasta procentowy udział tej grupy w populacji. I właśnie niniejsze zjawisko leży u podstaw kształtowania się starzejącego się społeczeństwa. J.-P. Bois, Historia starości. Od Montaignéa do pierwszych emerytur, przekł. K. Marczewska, przedm. G. Minois, Warszawa 1996, s. 12.

${ }^{4}$ G. Minois, Historia starości. Od antyku do renesansu, przekł.. K. Marczewska, przedm. J. Delumeau, Warszawa 1995, s. 12, 14.
} 
W ostatnich latach ukazało się kilka publikacji zbiorowych na temat starości w literaturze ${ }^{5}$. Wykorzystują one rozmaite konteksty interpretacyjne: psychologiczne, socjologiczne, pedagogiczne, kulturowe, biologiczne czy antropologiczne, przynosząc wielowymiarowy obraz doświadczenia człowieka w końcowej fazie egzystencji. Zainteresowanie omawianym problemem z pewnością ma źródło w jego niezwykłej aktualności w dzisiejszych czasach, które sprzyjają podejmowaniu dyskursu gerontologicznego. Równocześnie na tej płaszczyźnie jest jeszcze wiele luk domagających się wypełnienia. Jedna z nich znajduje się w pisarstwie Brunona Schulza — w poświęconych mu opracowaniach zagadnienie starości było do tej pory jedynie sygnalizowane, chociaż stanowi kluczowy motyw wielu opowiadań. Niniejsze studium podejmuje je w sposób szkicowy i nie pretenduje do wyczerpania problemu (a wymaga on dogłębnych studiów), ponieważ jest przedsięwzięciem inicjacyjnym. Analizie poddano tu utwory Emeryt i Samotność oraz kreację Jakuba (głównie na podstawie opowiadania Sanatorium pod Klepsydra).

Marek Szladowski zwrócił uwagę na to, że trudno wypowiadać się o starości, ponieważ w poświęconym jej dyskursie nie wykrystalizował się jeszcze język odpowiedni dla opisu takich doświadczeń ${ }^{6}$. Niełatwo również skatalogować rozmaite oblicza jesieni życia w literaturze pięknej w ujęciu syntetycznym, ponieważ późne lata człowieka $\mathrm{w}$ każdym przypadku są silnie naznaczone piętnem indywidualizmu ${ }^{7}$. Według Szladowskiego, badacz zajmujący się literackim obrazem ludzi w podeszłym wieku może wpaść w pułapkę zbyt wyszukanego stylu i nowoczesnych metodologii, które zaciemniają sens wywodu analityczno-interpretacyjnego. Dlatego też w przedmowie otwierającej tom Egzystencjalne doświadczenie starości w literaturze przekonuje:

Ważne, by w swoistym „dyskursie starości” sama starość pozostała w centrum, by efektowna stylistyka czy metodologiczne mody nie skaziły jej i nie przesłoniły. Być może to jedno z najtrudniejszych zadań, przed jakimi stanęli autorzy zamieszczonych w tomie tekstów: znaleźć język dla starości

Proponowaną przez niego postawą metodologiczną w tej sytuacji jest zmierzanie do bezpośredniości i dosłowności opisu? . Postulat ten został wykorzystany w praktyce w niniejszej pracy.

\footnotetext{
${ }^{5}$ Zob. Dojrzewanie do petni życia. Starość w literaturze polskiej i obcej, red. S. Kruk, E. Flis-Czerniak, Lublin 2006; Egzystencjalne doświadczenie starości w literaturze, red. A. Gleń, I. Jokiel, M. Szladowski, Opole 2008; Starość. Doświadczenie egzystencjalne, temat literacki, metafora kultury, red. A. Janicka, E. Wesołowska, G. Kowalski, koncepcja i wstęp J. Ławski, seria 1: Rozpoznania, Białystok 2013. Publikowane są także monografie dotyczące starości u poszczególnych pisarzy. Zob. K. Trybuś, Stary poeta. Studia o Norwidzie, Poznań 2000; Z. Mokranowska, Młodość i starość. Studia o twórczości Jarostawa Iwaszkiewicza, Katowice 2009.

${ }^{6}$ M. Szladowski, Starość w przedsionku śmierci (zamiast wstępu), [w:] Egzystencjalne doświadczenie starości w literaturze, s. 7.

${ }^{7}$ J.-P. Bois, dz. cyt., s. 313.

${ }^{8}$ M. Szladowski, dz. cyt., s. 8.

${ }^{9}$ Tamże.
} 
Bohaterem opowiadania Emeryt jest stary pan radca, emerytowany urzędnik bankowy, pełniący w utworze także funkcję pierwszoosobowego narratora. Warto zwrócić uwagę na to, że tytuł dzieła określa status społeczny protagonisty ${ }^{10}$.

Schulzowski emeryt to bez wątpienia człowiek, który miał do siebie duży dystans. Opowiadał on o swym życiu z ironią, która stała się ważną zasadą organizującą utwór. Staruszek przyjął postawę daleką od właściwej późnemu wiekowi stateczności:

Najlepiej, gdy się mnie traktuje z pewną lekkością, z pewną zdrową bezwzględnością, żartobliwie i po koleżeńsku. Pod tym względem moi poczciwi, prości duchem koledzy z biura, młodsi koledzy z urzędu utrafili ton właściwy ${ }^{11}$.

Pan radca nie chciał, by postrzegano go wyłącznie przez pryzmat jego starości bądź obchodzono się z nim ze specjalną troską:

Jednemu chciałbym zapobiec, by czytelnik nie robił sobie wygórowanych wyobrażeń o mojej kondycji. Przestrzegam wyraźnie przed przecenianiem jej, i to zarówno in plus, jak i in minus. Tylko żadnej romantyki. Jest to kondycja jak każda inna, jak każda inna nosząca w sobie znamię najnaturalniejszej zrozumiałości i zwyczajności ${ }^{12}$.

Bezpośredni zwrot do odbiorcy, typowy dla opowiadań Schulza, stanowi element przemyślanej strategii narracyjnej, której funkcją jest nawiązanie kontaktu z czytelnikiem i pozyskanie jego przychylności ${ }^{13}$. W tym kontekście adresat opowiadania stał się „figurą retoryczną służącą do imitowania sytuacji komunikacyjnej"14.

Emeryt postrzegał własny stan jako zwyczajny, ludzki i niewpływający w sposób zasadniczy na jego tożsamość. Jak stwierdził, „nic bardziej pozbawionego patosu, nic bardziej naturalnego, nic banalniejszego na świecie" ${ }^{15}$. Jednocześnie bohater ubolewał nad tym, że otoczenie uważało jego starość za temat tabu, robiąc wszystko, by ją przemilczeć:

Natrętne, nigdy nie wypowiedziane pytanie, które czytam ciągle w ich oczach. Niepodobna się od niego odpędzić. Przypuśćmy, że tak jest — dlaczego zaraz te wydłużone miny, te uroczyste twarze, to cofające się niejako z szacunku milczenie, ta przestraszona oględność? Ażeby tylko ani słówkiem nie potrącić, przemilczeć delikatnie mój stan... ${ }^{16}$.

\footnotetext{
${ }^{10}$ Jak wyjaśnia G. Minois, w krajach europejskich na przełomie XIX i XX wieku „»starzec« stał się »emerytem " i wraz z niewielkim dochodem zyskał określony status społeczny”. G. Minois, Przedmowa, [w:] J.-P. Bois, dz. cyt., s. 6.

${ }^{11}$ B. Schulz, Emeryt, [w:] Opowiadania. Wybór esejów i listów, oprac. J. Jarzębski, wyd. 2 przejrz. i uzup., Wrocław 1998, BN I 264, s. 309.

${ }^{12}$ Tamże, s. 311.

${ }^{13}$ W. Panas, „Zstapienie w esencjonalność. O ksztattach stowa w prozie Brunona Schulza, [w:] Studia o prozie Brunona Schulza, red. W. Wyskiel, Katowice 1976, s. 83.

${ }^{14}$ Tamże.

${ }^{15}$ B. Schulz, dz. cyt., s. 311.

${ }^{16}$ Tamże, s. 310. Zob. też pracę na temat milczenia: T. Cieślikowska, Przemilczenie w prozie. W kręgu teorii sugestii, [w:] O wartościowaniu w badaniach literackich, red. S. Sawicki, Lublin 1986, s. 245-254.
} 
Przywołane refleksje mają źródło w tym, że pan radca to zwolennik otwartego mówienia o doświadczeniach jesieni życia, źle odbierający nienaturalne zachowanie rozmówców.

Starość w ujęciu Schulzowskiego emeryta jest stanem swoistej wolności, niosącej za sobą brak odpowiedzialności za podejmowane działania. Na tej płaszczyźnie w sposób paradoksalny przypomina ona młodość. Senior wylicza:

Wielkie orzeźwienie [...], wyzbycie się wszystkich ciężarów, taneczna lekkość, pustka, nieodpowiedzialność, zniwelowanie różnic, rozluźnienie wszelkich więzów, rozprzęgnięcie się granic. Nic mnie nie trzyma i nic nie więzi, brak oporu, bezgraniczna swoboda ${ }^{17}$.

Bohater zdawał sobie sprawę z tego, że jego życie niebawem dobiegnie końca i, zdesperowany, chce czerpać z niego jak najwięcej, nie bojąc się konsekwencji. Na tym polegał relatywizm emeryta w odczuwaniu starości.

Pan radca, źle znosząc swoją pustą i monotonną egzystencję, poszukuje kontaktu z ludźmi i zajęcia. Często przychodzi do dawnego miejsca pracy, by odwiedzić młodszych kolegów-bankowców bądź pomóc im w pełnieniu obowiązków. Przyjmowali oni wobec niego postawę pełną serdeczności, nie stroniąc przy tym od ciepłego humoru:

— Usłyszałem jakiś głos w przestworzach i zaraz pomyślałem sobie, że to musi być nasz kochany pan radca! — woła on głośno, z natężeniem, jakby do kogoś bardzo odległego. [...] Wolne żarty, panie Kawałkiewicz — mówię mu cicho prosto w twarz — przyszedłem po moją pensję. — Po pensję? — krzyczy pan Kawałkiewicz, patrząc zezowato w powietrze - pan powiedział: po pensję. Pan żartuje, kochany panie radco. Pan już dawno skreślony jest z listy emerytalnej. Jak długo pan chce pobierać jeszcze pensję, laskawy panie? ${ }^{18}$.

Życzliwa ironia dobrze trafia we wrażliwość bohatera, który czuł się podniesiony na duchu dzięki takim spotkaniom:

W ten sposób żartują sobie ze mnie w sposób ciepły, ożywczy i ludzki. Ta szorstka rubaszność, ten bezceremonialny chwyt za ramię sprawia mi dziwną ulgę. Wychodzę stamtąd pokrzepiony i raźniejszy i śpieszę prędko do domu, żeby zanieść do mieszkania trochę tego miłego wewnętrznego ciepła, które się już ulatnia ${ }^{19}$.

Tymczasem sytuacja znacznie pogorszyła się w momencie, kiedy zmieniła się naczelnik biura, co wymusiło na emerycie zaprzestanie inicjowania podobnych spotkań. Wtedy bohater zaczął spędzać czas, siedząc na ławce i obserwując dzieci uczęszczające do pobliskiej szkoły. Szybko zwrócił on uwagę urwisów, którzy traktowali go jak rówieśnika. Zapewne dlatego, że starość uczyniła emeryta osobą zdziecinniałą. Co wię-

\footnotetext{
${ }^{17}$ B. Schulz, dz. cyt., s. 311.

${ }^{18}$ Tamże, s. 309.

${ }^{19}$ Tamże, s. 310.
} 
cej, sprawiła też, że po trosze upodobnił się fizycznie do najmłodszych przedstawicieli pokolenia. Wszakże bohater mówił o sobie: „Mój wzrost znajduje się od dawna w zaniku. Twarz moja rozluźniona i zwiotczała przybrała pozór dziecinnej"20. Jean-Pierre Bois zauważył, że „kruchość starego człowieka może go jednak uczynić na tyle bliskim dziecka, że wyraża niewinność i czystość” ${ }^{21}$.

Emeryt zaprzyjaźnił się z uczniami, z czasem stając się pełnoprawnym członkiem ich grupy. Co prawda mali koledzy mu dokuczali, ale spełniało to oczekiwania starca, który nie życzył sobie, żeby mieć wobec niego jakiekolwiek skrupuły. Pan radca, fraternizując się z młodzieżą, zaspokajał swoje poczucie przynależności. Miejsce konfliktu między młodymi a starymi zajęła tu względnie udana koegzystencja obu tych grup. Naturalnie, zachowanie emeryta było również znakiem infantylizmu, powrotu do dzieciństwa za wszelką cenę, a może nawet wyrazem starczego zaburzenia bystrości i jasności umysłu bądź dezintegracji osobowości.

Ale to nie wszystko. Wkrótce senior postanowił jeszcze silniej zintegrować się z nowym środowiskiem i... zapisać się do szkoły. Dyrektor zareagował na to aprobatywnie, choć cała sytuacja miała wydźwięk głęboko ironiczny i groteskowy:

— Pan radca chciałby zapisać się do pierwszej klasy? — rzekł. — Bardzo chwalebne i godne uznania. Rozumiem, radca chcesz od podstaw, od fundamentów swą edukację odbudować. Zawsze powtarzam: gramatyka i tabliczka mnożenia oto są podstawy wykształcenia ${ }^{22}$.

Bohater zrzekł się wszelkich przywilejów, jakie przysługiwały mu z racji statusu hospitanta, gdyż chciał „zniknąć w szarej masie klasy" ${ }^{23}$. Niebawem dyrektor, biorąc go za rękę, zaprowadził go do klasy i przedstawił uczniom, tłumacząc, że jest sierotą. Senior odebrał to jako analogiczną sytuację do tej, której doświadczył wiele lat temu, gdy wraz z matką po raz pierwszy poszedł do szkoły.

Stary pan radca, ucząc się wszystkiego od podstaw, odkrywał świat na nowo. Opis szkolnej codzienności jest przejawem charakterystycznej dla pisarstwa Schulza estetyki przepełnienia i ukazuje emeryta jako ośrodek działań dzieci:

Przesyłano mi sygnały, telegramy, dawano znaki porozumiewawcze, psykano, mrugano i na wszystkie sposoby przypominano mi na migi tysiące zobowiązań, które zaciągnąłem. Ledwo mogłem się doczekać do końca lekcji, podczas której z wrodzonej przyzwoitości wytrzymywałem ze stoicyzmem wszystkie ataki, żeby ani słowa nie uronić $\mathrm{z}$ nauk pana profesora ${ }^{24}$.

Jerzy Speina zauważył, że powrót do szkoły po latach dokonał się tutaj w zupełnie inny sposób niż w Ferdydurke Witolda Gombrowicza. O ile Schulzowski senior chciał

\footnotetext{
${ }^{20}$ Tamże, s. 316. W tym krótkim opisie ujawnia się charakterystyczne dla Schulzowskiej prozy rozprzężenie kształtu.

${ }^{21}$ J.-P. Bois, $d z$. cyt., s. 314.

${ }^{22}$ B. Schulz, dz. cyt., s. 318.

${ }^{23}$ Tamże.

${ }^{24}$ Tamże, s. 320.
} 
na nowo stać się podmiotem edukacji, o tyle Józio z dzieła autora Pamiętnika z okresu dojrzewania odbierał analogiczną okoliczność jako zmuszenie go do przyjęcia obcej mu tożsamości ${ }^{25}$.

Niezwykłej siły wyrazu nabrała scena, w której bohater, odczuwając skruchę z powodu bliżej nieznanych wybryków, do jakich posunął się wraz z kolegami, z własnej woli chciał poddać się karze cielesnej:

Z obojętnością rozpiąłem pasek, ale pan dyrektor, spojrzawszy, zawołał: — Wstyd, czy to możliwe? w tym wieku? [...] — Dziwny wybryk natury — dodał z grymasem wstrętu. Potem, odprawiwszy malców, miał do mnie długie i poważne kazanie, pełne żalu i dezaprobaty ${ }^{26}$.

Ganiące komentarze dyrektora mogły wynikać zarówno z samego występku staruszka, jak i z tego, próbował on obnażyć swoje ciało, co wzbudziło w pryncypale zażenowanie.

Emeryt podsumował to doświadczenie słowami: „Byłem już naprawdę dzieckiem”27. Przyjąwszy tę tożsamość osiągnął ideał „dojrzałości dzieciństwa”, która w ujęciu autora Genialnej epoki nastąpiła wyłącznie w wieku dojrzałym ${ }^{28}$.

Niestety, starzec nie cieszył się rolą pierwszoklasisty zbyt długo. W chwili nieuwagi kolegów został bowiem porwany przez silny, jesienny wiatr, który zaniósł go „wyżej i wyżej w żółte niezbadane przestworza"29 — i nikt nie mógł mu pomóc. Z kolei dyrektor, dowiedziawszy się o tym nietypowym wypadku, był całkowicie obojętny i natychmiast kazał wykreślić emeryta z listy uczniów. Wiatr symbolizuje tutaj niestałość, nicość, przemijanie i zmienność życia pana radcy ${ }^{30}$.

\begin{abstract}
${ }^{25}$ J. Speina, $d z$. cyt., s. 62. B. Schulz przyjaźnił się z W. Gombrowiczem i był wnikliwym czytelnikiem Ferdydurke. Esej drohobyckiego artysty na temat tej powieści zapisał się w historii polskiej krytyki literackiej i odegrał dużą rolę w ugruntowaniu pozycji autora Pamiętnika z okresu dojrzewania. Zob. B. Schulz, Ferdydurke, „Skamander” 1938, z. 96-98, s. 183-189; przedr. [w:] tenże, Opowiadania, dz. cyt., s. 398408; M. Bartosik, Schulz jako krytyk, Kraków 2000. Zbieżność motywu powrotu do szkoły po latach w Emerycie i w Ferdydurke najprawdopodobniej jest jednak przypadkowa — nie wynika ze świadomego nawiązania, ale za to potwierdza wspólne cechy wyobraźni obu autorów. Wskazuje na to fakt, że opowiadanie B. Schulza zostało opublikowane na łamach „Wiadomości Literackich” w 1935 roku, a powstało najpewniej, jak większość utworów z Sanatorium pod Klepsydra, wiele lat wcześniej, podczas gdy powieść Ferdydurke ukazała się dopiero w 1937 roku. Zob. B. Schulz, Emeryt, „Wiadomości Literackie” 1935, nr 51-52, s. 16-17. Ewentualna gra intertekstualna Wielkiego Drohobyczanina z Gombrowiczem musiałaby wynikać z poznania przez niego koncepcji utworu najpóźniej w 1935 roku, na co były nikłe szanse. Bardziej prawdopodobna byłaby natomiast sytuacja odwrotna, tzn. taka, że autor Ferdydurke inspirował się opowiadaniem B. Schulza.
\end{abstract}

${ }^{26}$ Tenże, Emeryt, [w:] tenże, Opowiadania, s. 321.

${ }^{27}$ Tamże.

${ }^{28}$ B. Schulz wyjaśnił tę kwestię w liście do Stanisława Ignacego Witkiewicza, będącym jedną z jego najważniejszych wypowiedzi na temat sztuki. Zob. tenże, Do Stanisława Ignacego Witkiewicza, [w:] tenże, Księga listów, zebrał i przygotował do druku J. Ficowski, wyd. 3, Gdańsk 2008, s. 99-103.

${ }^{29}$ Tenże, Emeryt, s. 325.

${ }^{30}$ Zob. W. Kopaliński, Wiatr, [w:] tenże, Stownik symboli, wyd. 2, Warszawa 1991, s. 455. 
Omawiany utwór zerwał ze stereotypowym utożsamieniem podeszłego wieku z powagą, wiedzą i doświadczeniem. W zamian ukazał perypetie człowieka odrzucającego swoją starość. Mimo deklaracji, która nakazywała przyjąć, że w pełni akceptował on swój stan. Ponowne przeżycie dzieciństwa do pewnego stopnia dokonało się tu z powodzeniem, jednak szybko zyskało niekorzystny dla seniora obrót w postaci ingerencji w jego los nieujarzmionych sił przyrody. Emeryt stanowił interesującą konkretyzację wątku przemijania egzystencji w jej finalnym etapie i pokazał, że starzec chcący na przekór upływowi czasu odzyskać utraconą młodość staje się zarazem śmieszny i tragiczny.

Inny obraz jesieni życia przynosi opowiadanie Samotność. Ukazało się ono w 1936 roku na łamach czasopisma "Studio" pod wymownym tytułem $O$ sobie, sugerującym związek autora z zaprezentowaną postacią, a w kolejnym roku zostało włączone do tomu Sanatorium pod Klepsydra ${ }^{31}$.

Przedstawiony tutaj staruszek, podobnie jak we wcześniejszym utworze pełniący rolę narratora, skazany został na egzystencję w całkowitym odosobnieniu, ponieważ z czterech ścian jego pokoju nie było wyjścia. Obraz ten można odczytać jako symboliczne ukazanie stanu wycofania się człowieka z czynnego życia i utratę przez niego więzi z zewnętrznym światem. Co więcej, bohater w tym samym pomieszczeniu spędził swoje dzieciństwo, wskutek czego doświadczenie starości sprzęgło się w jego wyobraźni z wypartymi wspomnieniami młodości:

Nie potrafię wytłumaczyć faktu, że jest to dawny mój pokój z dzieciństwa, ostatnia izba od ganku już za owych czasów rzadko odwiedzana, wciąż zapominana, jakby nie należąca do mieszkania ${ }^{32}$.

W jesieni życia Schulzowski protagonista stał się dla samego siebie kimś obcym i nie poznawał własnego odbicia w zwierciadle:

Jak wyglądam? Czasem widzę się w lustrze. Rzecz dziwna, śmieszna i bolesna! Wstyd wyznać. [...] Przecież to ty, chciałbym zawołać, byłeś moim wiernym odbiciem, towarzyszyłeś mi tyle lat, a teraz nie poznajesz mnie! ${ }^{33}$.

Zacytowane słowa wskazują na jego trudności w samoakceptacji, zapewne wynikające ze starzenia się ciała, którego obcy wygląd nie przystawał do obrazu utrwalonego w przeszłości. Semantyka tej sceny współgra z paradygmatem znaczeń opisanym w Stowniku symboli Władysława Kopalińskiego. Zgodnie z nim lustro to między innymi „narzędzie samooglądu, samopoznania, refleksji nad sobą”, mogące być także

\footnotetext{
${ }^{31}$ Zob. B. Schulz, O sobie, „Studio” 1936, nr 2, s. 11-13.

${ }^{32}$ Tenże, Samotność, [w:] tenże, Opowiadania, s. 325. Wypowiedź staruszka zawiera wyraźne nawiązanie do psychoanalizy w wersji Freudowskiej. Zob. Z. Freud, Wstęp do psychoanalizy, przekł. S. Kepmnerówna, W. Zaniewicki, przedm. K. Obuchowski, wyd. 11, Warszawa 2003.

${ }^{33}$ B. Schulz, Samotność, s. 326-327.
} 
zwiastunem „dwoistości, rozdwojenia, ambiwalencji”34. Zwierciadło, przedmiot delikatny i łamliwy, można także odczytać jako motyw odsyłający do kruchości życia starca $^{35}$.

Bohater opowiadania — tak jak stary Jakub — doświadczył metamorfozy zwierzęcej i przeobraził się w mysz ${ }^{36}$. Gryzoń ten symbolizuje między innymi smutek, śmierć, bojaźliwość, znikomość, błahość, małość, niską pozycję społeczną, ale także rozum i spryt ${ }^{37}$. W perspektywie wymienionych znaczeń przemiana staruszka wydaje się materializacją jego bezradności (bojąc się świata, chce od niego uciec), choć jednocześnie wypowiedział on głęboką refleksję, czym dowodził swego silnego związku z rzeczywistością. Otóż bohater robił sobie wyrzuty i ujmował je w kształt monologu stylizowanego na proroctwo biblijnego Jakuba:

Siedzę tu od lat i nudzę się. Gdybym był zawczasu myślał o robieniu zapasów! Ach wy, którzy jeszcze możecie, którym dany jest jeszcze własny czas na to, zbierajcie zapasy, ciułajcie ziarno, dobre i pożywne, słodkie ziarno, bo przyjdzie wielka zima, przyjdą lata chude i głodne i nie obrodzi ziemia w egipskim kraju. Niestety nie byłem jak skrzętny chomik, byłem jak lekkomyślna mysz polna, żyłem z dnia na dzień bez troski o jutro, dufny w swój talent głodomora ${ }^{38}$.

Mówiąc o potrzebie robienia zapasów na „chude lata”, senior najpewniej miał na myśli konieczność przygotowania się do starości — przede wszystkim pod względem relacji z ludźmi, co stanowić miałoby jedyny sposób na uniknięcie samotności w jesieni życia.

Daniel Kalinowski dostrzegł w analizowanym utworze intertekstualne nawiązanie Schulza do twórczości Franza Kafki ${ }^{39}$. Według badacza, mysz jest tutaj motywem za-

\footnotetext{
${ }^{34}$ W. Kopaliński, Lustro, [w:] tenże, Stownik symboli, s. 207.

${ }^{35}$ Tamże, s. 208.

${ }^{36}$ Zob. pracę na temat zwierząt w twórczości Schulza: A. Ossowski, Drohobyckie bestiarium, [w:] Bruno Schulz in memoriam 1892-1942, red. M. Kitowska-Łysiak, wyd. 2, Lublin 1994, s. 79-99.

${ }^{37}$ W. Kopaliński, Mysz, [w:] tenże, Stownik symboli, s. 245.

${ }^{38}$ B. Schulz, Samotność, s. 325-326. Autor Sanatorium pod Klepsydra bardzo często sięgał do tradycji biblijnej — zarówno do bliskich mu wątków ze Starego Testamentu, jak i w zakresie poetyki. Zob. A. Kalin, Watki biblijne w prozie Brunona Schulza, [w:] Między ortodoksja a obrazoburstwem. Postaci i motywy biblijne, red. J. Borowczyk, A. Kwiatkowska, D. Rojszczak, Poznań 2006, s. 101-113.
}

${ }^{39}$ D. Kalinowski, Kafka wedtug Schulza, [w:] tenże, Światy Franza Kafki. Sekwencja polska, Słupsk 2006, s. 86-88. Twórczość Kafki była niezwykle inspirująca dla Schulza, o czym świadczą zarówno wypowiedzi artysty na kartach korespondencji, jak i powołanie przez niego do życia świata, który posiadał wiele cech wspólnych z rzeczywistością autora Zamku. Warto przy okazji dodać, że narzeczona Wielkiego Drohobyczanina Józefina Szelińska przełożyła na język polski Proces, który został opublikowany pod nazwiskiem Schulza ze względu na jego uznanie w kręgach elit intelektualno-artystycznych międzywojnia. Tłumaczenie to jest w powszechnym użyciu do dziś. Zob. F. Kafka, Proces, przekł. B. Schulz, wstęp P. Kuncewicz, Warszawa 1996. Zob. również opracowanie na temat intertekstualności: M. Głowiński, O intertekstualności, [w:] tenże, Prace wybrane, t. 5: Intertekstualność, groteska, parabola. Szkice ogólne i interpretacje, Kraków 2000, s. 5-33. 
czerpniętym z opowiadania autora Procesu zatytułowanego Schron, w którym bliżej nieokreślony gryzoń zbudował wokół siebie zamkniętą przestrzeń, chcąc w niej spokojnie i bezpiecznie żyć ${ }^{40}$. Kalinowski wyjaśnił:

Zwierzę jest bardzo konsekwentne i metodyczne w budowie schronu czy też jamy, nie może jednak znaleźć w swojej budowli spokoju, ponieważ prześladuje go [tak!] wrażenie jakiegoś ruchu z zewnątrz, zagrożenia z czyjejś strony. U Schulza poczucie zagrożenia również jest obecne, choć, jak przyznaje zwierzęcy bohater: „Przykładam ucho do drzewa, czy tam w głębi robak nie chrobocze. Grobowa cisza”ł1.

Jednakże w przeciwieństwie do postaci Kafki Schulzowski starzec-mysz przełamał się w swoim odizolowaniu i zdecydował się na wejście w związek z zewnętrznym światem. Wyjaśnit, że jego metamorfozę „należy naturalnie rozumieć metaforycznie”² i tym sposobem odkrył własną tożsamość:

Należy to do właściwości mojej egzystencji, że pasożytuję na metaforach, daję się tak łatwo ponosić pierwszej lepszej metaforze. Zapędziwszy się tak, muszę dopiero z trudem odwoływać się z powrotem, wracając powoli do opamiętania ${ }^{43}$.

Przytoczone stwierdzenie dowodzi, że ukazany tu emeryt to artysta. Pod jego maską może znajdować się także Bruno Schulz — człowiek samotny i szukający ucieczki od rzeczywistości w sztuce (hipotezę tę zdaje się potwierdzać pierwotny tytuł utworu). I tak możliwość opuszczenia przestrzeni zamurowanego pokoju i położenie kresu alienacji stworzyła zbawcza siła wyobraźni:

Czy mam zdradzić, że pokój mój jest zamurowany? Jakżeż to? Zamurowany? W jakiż sposób mógłbym zeń wyjść? Otóż to właśnie: dla dobrej woli nie ma zapory, intensywnej chęci nic się nie oprze. Muszę sobie tylko wyobrazić drzwi, dobre stare drzwi, jak w kuchni mego dzieciństwa, z żelazną klamką i ryglem. Nie ma pokoju tak zamurowanego, żeby się na takie drzwi zaufane nie otwierał, jeśli tylko starczy sił, by mu je zainsynuować ${ }^{44}$.

Jest ona bowiem władna kreować świat na nowo, nie zna żadnych ograniczeń i wzbogaca życie o promienistą moc poezji.

Kalinowski zauważył, że fragment ten zawiera kolejne świadome odwołanie Schulza do pisarstwa autora Zamku, tym razem do słynnej przypowieści Przed prawem ${ }^{45}$, drukowanej najpierw w zbiorze Wyrok, a później funkcjonującej jako część Procesu. Oto kluczowy cytat z Kafkowskiej paraboli, opisujący postawę człowieka ze wsi, który chciał przejść przez pilnie strzeżoną bramę (symbolizującą zewnętrzną rzeczywistość), jednak nie uzyskał na to zgody:

\footnotetext{
${ }^{40}$ D. Kalinowski, $d z$. cyt., s. 87.

${ }^{41}$ Tamże.

${ }^{42}$ B. Schulz, Samotność, s. 326.

${ }^{43}$ Tamże.

${ }^{44}$ Tamże, s. 327.

${ }^{45}$ D. Kalinowski, $d z$. cyt., s. 87-88.
} 
Człowiek ze wsi nie spodziewał się takich trudności; prawo powinno być przecież dostępne dla wszystkich i zawsze, myśli sobie, lecz gdy dokładniej ogląda teraz strażnika [...], postanawia jednak raczej zaczekać, aż otrzyma pozwolenie na wejście. Strażnik podaje mu stołek i pozwala mu usiąść z boku przed bramą. Siedzi tam dniami i latami ${ }^{46}$.

Bohater nie podejmował większej inicjatywy i wykonywał wszystkie polecenia strażnika, przed samą śmiercią dowiadując się, że był jedyną osobą, która mogła przejść przez zamkniętą bramę. Według Kalinowskiego, Schulz nawiązał do przypowieści autora Ameryki „nie tyle poprzez określenie pozycji człowieka wobec Prawa, co dzięki zasygnalizowaniu sytuacji trudności, konsekwencji i odpowiedzialności wyboru”47 . Innymi słowy, protagonista Kafki sądził, że jego los determinowały czynniki zewnętrzne i cierpliwie czekał, aż wydarzy się coś, co zmieni jego położenie (zamiast szukać innych możliwości wyjścia z sytuacji), natomiast starzec z opowiadania Samotność przełamał rezygnację i bierność swojego poprzednika. Przyjmując aktywną postawę wobec własnego problemu, kluczową rolę w jego rozwiązaniu przyznał sile woli i wyobrá́ni. „Dobre stare drzwi” stały się tu symbolem „przejścia między jednym światem albo stanem a drugim, między światłem a ciemnością, między znanym a nieznanym, codziennością i krainą tajemnic" ${ }^{48}$.

Samotność obrazuje starość z punktu widzenia artysty, ale obecne tu przesłanie można odnieść do każdej osoby w podeszłym wieku. Tytułowe doświadczenie objęło zarówno trudności czy brak perspektyw na nawiązanie relacji z ludźmi, jak i wewnętrzną alienację, rozumianą jako utratę poczucia związku z samym sobą. To prawda, że starzec $\mathrm{z}$ omawianego opowiadania z entuzjazmem mówił o sztuce i potędze fantazji, które miały mu pomóc w przezwyciężeniu samotności. Jednak trzeba mieć na uwadze, że takie lekarstwa zwykle stanowią tylko tymczasowy środek zaradczy i nie zastąpią więzi międzyludzkich (wszakże utwór ten traktował o cierpieniu wywołanym brakiem satysfakcjonujących relacji). Stąd też płynie sugestywnie wyartykułowany postulat bohatera, by odpowiednio wcześniej przygotować się do „chudych lat”.

Starość jest również tematem Sanatorium pod Klepsydra, utworu, który nadał tytuł drugiemu tomowi opowiadań Schulza. Zasady obowiązujące w jego onirycznej quasirzeczywistości umożliwiły cofnięcie czasu i sprawiły, że Józef spotkał się z nieżyjącym już Jakubem w nietypowym zakładzie leczniczym. Oto jak tajemniczy doktor Gotard wyjaśnił to zjawisko:

Cały trick polega na tym — dodał, gotów mechanizm jego demonstrować na palcach, już ku temu przygotowanych - że cofnęliśmy czas. Spóźniamy się tu z czasem o pewien interwał, którego wielkości

\footnotetext{
${ }^{46}$ F. Kafka, Przed prawem, [w:] tenże, Wyrok, przekł. J. Kydryński, Warszawa 1992, s. 85.

${ }^{47}$ D. Kalinowski, $d z$. cyt., s. 87.

${ }^{48}$ W. Kopaliński, Drzwi, [w:] tenże, Stownik symboli, s. 75.
} 
niepodobna określić. Rzecz sprowadza się do prostego relatywizmu. Tu po prostu jeszcze śmierć ojca nie doszła do skutku, ta śmierć, która go w pańskiej ojczyźnie już dosięgła ${ }^{49}$.

Tak więc życie Jakuba zostało przedłużone wskutek opanowania żywiołu czasu i wstrzymania go w momencie, w którym bohater jeszcze żył. Czy jednak tak prolongowane istnienie ojca można uznać za pełne i wielowymiarowe? Bez wątpienia nie. To raczej cząstkowa egzystencja i trwanie w stagnacji — choć jej niekwestionowaną wartością jest oddalenie widma śmierci.

W tym miejscu uzasadnione staje się postawienie hipotezy, że w opowiadaniu $S a$ natorium pod Klepsydra Schulz, niczym nieomylny prorok, przedstawił przemiany kulturowe towarzyszące umieraniu, polegające na tym, że znacznie więcej ludzi niż kiedyś osiągało późny wiek, lecz z biegiem czasu zapadali oni na choroby przewlekłe, których powolny przebieg wydłuża egzystencję, ale jednocześnie powoduje, że osoby starsze wymagają stałej opieki, nieraz przez wiele lat. Proces ten rozpoczą się w latach 30. XX wieku w krajach zachodnich (a więc w epoce Schulza), z czasem nasilił się, a dziś stanowi zjawisko, które nikogo nie dziwi ${ }^{50}$. W takiej sytuacji chorym najczęściej zajmuje się rodzina, co nierzadko implikuje szereg problemów. Socjolog medycyny Magdalena Sokołowska wyjaśnia:

Ten „dodany czas”, wynikający w dużej mierze ze wzrostu skuteczności leczenia, może być dobrodziejstwem dla pacjenta, gdyż pozwala na uczestniczenie w życiu rodzinnym i uporządkowanie swoich spraw. Z drugiej strony jednak niesie za sobą nowe problemy. [...] Sytuacja ta staje się trudna dla członków rodziny, którzy nie są w stanie żyć tak jak poprzednio [...]. Stosunki, jakie często powstają między żyjącymi a umierającymi, stają się napięte i skrępowane ${ }^{51}$.

Kiedy najbliżsi nie mogą lub nie chcą podjąć się opieki nad taką osobą, czasami dochodzi do tego, że zostaje ona umieszczona w zakładzie dla ludzi w podeszłym wieku lub w innym obiekcie szpitalnym — choć większość chorych pragnie, aby opiekowali się nimi najbliżsi i chciałaby umrzeć we własnym domu.

Literatura piękna i malarstwo uwieczniły obraz umierającego człowieka. Chorował on i umierał bardzo uroczyście w swoim domu. Całe otoczenie czuło bliskość śmierci, każdy członek rodziny uczestniczył w tym zdarzeniu. Obecnie [...] śmierć nie jest już okazją do równie uroczystych ceremonii. Główną przyczyną tej sytuacji ma być współczesne zjawisko skrycia śmierci w murach szpitala. Człowiek stracił przywilej umierania w znanym mu otoczeniu, w kręgu trzymających wartę najbliższych. Teraz lekarze i zespół szpitalny stali się „mistrzami śmierci”, według tych poetycznych określeń5 ${ }^{52}$.

Sokołowska określiła to zjawisko mianem hospitalizacji śmierci ${ }^{33}$. Zacytowane fragmenty Socjologii medycyny, choć opisują współczesne realia, stanowią arcytrafny

\footnotetext{
${ }^{49}$ B. Schulz, Sanatorium pod Klepsydra, [w:] tenże, Opowiadania, s. 267.

${ }^{50}$ M. Sokołowska, Socjologia medycyny, Warszawa 1986, s. 127.

${ }^{51}$ Tamże, s. 121.

52 Tamże, s. 127.

${ }^{53}$ Tamże.
} 
komentarz do Schulzowskich opowiadań. Stary Jakub przedstawiony jest w nich jako człowiek w podeszłym wieku i schorowany. Znakiem jego starości są między innymi metamorfozy zwierzęce - przeobraził się on w kondora, karalucha i raka, określanego też zamiennie jako krab i skorpion ${ }^{54}$. Mimo upływu czasu i pojawiających się informacji o jego odejściu nadal żył wraz z rodziną i ukazywał się w nowych wcieleniach, ale nie mógł liczyć na wsparcie domowników. W każdej sytuacji pozostawiali go oni samemu sobie bądź chcieli się go pozbyćc 55 .

W świetle obecnych rozważań uzasadniona jest konstatacja, że kreacja ojca, który mimo starości i chorób nie umarł, a także negatywna wobec niego postawa najbliższych - stanowią przejmującą wizję powolnej śmierci, pozwalającej tylko na połowiczne istnienie, będącej balastem dla rodziny i mającej swoją konsekwencję w wegetacji w nieprzyjaznym zakładzie leczniczym. Ważkie dopełnienie tego obrazu przyniosło zakończenie opowiadania Sanatorium pod Klepsydrą: Józef pozostawił bezbronnego ojca w szpitalnym pokoju z przerażającym człowiekiem-psem, sam zaś uciekł.

Podsumowując wnioski, należy stwierdzić, że utwór ten, ukazując materialno-fantastyczną rzeczywistość, zarysował problem niegodnego życia seniorów, którzy mając coraz mniej sił, powoli odchodzą ze świata żywych — i jednocześnie nie dał żadnej odpowiedzi na pytanie, w jaki sposób uczynić ich egzystencję bardziej ludzką. Kwestia ta po dziś dzień pozostaje nierozstrzygnięta, a pewne jest tylko jedno — do starości trzeba się przygotować, a kluczową rolę odgrywają w tym prawidłowe relacje z najbliższymi.

Interpretacja utworów Emeryt, Samotność i Sanatorium pod Klepsydra dowodzi, jak niezwykłym wizjonerem jest Schulz, który przedstawił w swoich opowiadaniach wielowymiarowy obraz starości, aktualny po dziś dzień, choć w jego czasach problemy te można było dostrzec tylko w zalążkach. I choć pisarz nie wyjaśnił, jak je rozwiązać, postawił zdecydowany krok w kierunku zmiany na lepsze, gdyż dzięki sugestywnemu ukazaniu trudów życia osób w podeszłym wieku wzbudził w odbiorcy wrażliwość na ich potrzeby.

Aleksandra Smusz

Variations on a Theme of Old Age in the Stories by Bruno Schulz

Summary

The article raises, so far overlooked in the gerontological literature, question of old age based on the compositions: Pensioner, Loneliness and Sanatorium Under the Sign of the Hourglass by Bruno Schulz. According to the aforementioned concept, the author of The Cinnamon Shops unites poetic prose with

\footnotetext{
${ }^{54}$ Metamorfozy zwierzęce są konsekwencją starczego rozprzężenia kształtu. Zob. J. Jarzębski, Schulz, Wrocław 1999, s. 184.

${ }^{55}$ Warto podkreślić interesujący paradoks: zachowanie najbliższych Jakuba stanowiło całkowite zaprzeczenie zasad religii Mojżeszowej, która nakazywała rodzinie opiekować się starcami i odnosić się do nich ze czcią — mimo że tradycja tego wyznania jest wyraźnie obecna w Schulzowskiej prozie.
} 
broadly defined and still valid social issues. Schulz depicts the autumn of life as having numerous faces - it is associated with various experiences such as returning to childhood and youth at all costs, loneliness, lack of care and interest on the part of loved ones, finally leading to isolation and social exclusion. However, the writer describes these aspects without any pathos, often using irony and reviving presented images with a use of fantastic elements.

Słowa kluczowe: starość, opowiadania Brunona Schulza, gerontologia

Keywords: old age, Bruno Schulz’s stories, gerontology 